\title{
Editorial
}

\section{COVID-19 Vaccines: Hope at Last}

\author{
Kishore Mangal ${ }^{1}$, Rajeev Gupta ${ }^{2}$ \\ ${ }^{I}$ Senior Consultant, Department of Critical Care Medicine, Eternal Heart Care Centre and Research Institute, \\ ${ }^{2}$ Editor, RUHS Journal of Health Sciences; Chair, Academic and Research Development Unit, Rajasthan University \\ of Health Sciences, Jaipur, Rajasthan, India \\ DOI:10.37821/ruhsjhs.5.4.2020.363
}

Within a year of its emergence, COVID-19 or second severe acute respiratory syndrome due to novel coronavirus (SARS CoV-2) has progressed rapidly to emerge as one of the largest pandemics that the world has encountered. By mid-December 2020, it has led to more than 1.7 million deaths and more than 76 million cases have been reported worldwide. In India, the disease has led to more than 140,000 deaths and 10 million cases. ${ }^{1}$ The number of cases all over the world could be an underestimate and the real count could be 10-40 times greater as has been shown in studies from New York and Iceland. High transmissibility of the virus and rapid spread from China to Europe, the Americas, South Asia and Africa, and devastation of economies in many of such countries, has led to genuine worldwide panic. Since public health response was initially slow and containment, prevention, and treatment strategies not developed; a veritable pandemic of misinformation and placebos have occurred.

No single strategy in isolation has proven to be useful for prevention and control of COVID-19 and therefore it is imperative that policy makers and public health officials continue to focus on established non-pharmacological interventions such as masking, physical distancing and avoiding crowded spaces. These interventions have been deployed with some success in the past influenza pandemics and continue to be important. As with other infectious diseases, vaccines offer an important preventive strategy for COVID-19. Although vaccines are important advance in prevention of the infection, we posit that proven physical measures must be continued till the time a sufficient proportion of population is vaccinated.

\section{VACCINES}

Modern diagnostic innovations led to rapid identification of structure of the novel coronavirus. They are enveloped, positive sense single-stranded RNA viruses. The glycoprotein spike on the surface ( $\mathrm{S}$ protein) mediates receptor binding and plays a critical role in cell entry during infection. This makes spike protein an attractive vaccine antigen. Almost all manufacturers are targeting spike protein as antigen apart from whole-virion inactivated vaccine. ${ }^{2}$ This has accelerated identification of vaccine candidates, and clinical trials of vaccines. Currently, 56 vaccine trials are in clinical stage and 166 trials are in preclinical stage. $^{3}$

Traditionally, vaccines are manufactured either as inactivated, live attenuated, or subunit, but various institutions and manufacturers are trying new techniques. It is unclear which vaccine strategies would be most successful. Therefore, it is important to invest in various vaccine strategies simultaneously. There are at least eight vaccine production strategies being evaluated and most rely on different viruses or viral parts (Table 1). ${ }^{4,5}$ Among those with the greatest potential for speed of production are RNA and DNA based platforms, followed by recombinantsubunit vaccines. The world has now witnessed the deployment of first RNA vaccine/s as successful agents for prevention of COVID-19. This is a significant event in the history of vaccine development. ${ }^{6}$

Since no corner of the world has left been untouched, unprecedented efforts have been put to find and develop therapeutics and vaccines. Various international alliances have been facilitating collaboration, research, and communication and are raising billions of dollars of fund from public, private, philanthropic, and civil society organizations. WHO has also implemented COVID- 19 Vaccines Global Access (COVAX) program for coordinating global vaccine development. Presently, 189 countries are part of this plan, which ensures that each country receive a guaranteed share of doses of licensed 
RUHS Journal of Health Sciences, Volume 5 Number 4, October-December 2020

Table 1: Overview of vaccine candidates for COVID-19,5+

\begin{tabular}{|c|c|c|c|c|}
\hline Vaccine type & $\begin{array}{c}\text { Mechanisms and } \\
\text { development }\end{array}$ & Advantage & Disadvantages & $\begin{array}{c}\text { Candidates in human } \\
\text { trials }\end{array}$ \\
\hline $\begin{array}{l}\text { Live-attenuated } \\
\text { vaccines }\end{array}$ & $\begin{array}{l}\text { Attenuated pathogen, } \\
\text { product development and } \\
\text { manufacturing process is } \\
\text { highly established }\end{array}$ & $\begin{array}{l}\text { Potent and long lasting } \\
\text { immune response, } \\
\text { single dose, long expe- } \\
\text { rience, no adjuvant }\end{array}$ & $\begin{array}{l}\text { Requires handling live virus, } \\
\text { slow process of manu- } \\
\text { facturing, stringent quality } \\
\text { control }\end{array}$ & $\begin{array}{ll}\text { - } & \text { Codagenix/Serum } \\
\text { Institute of India } \\
\text { - } & \text { Sinopharm + Beijing } \\
\text { Institute of Biological } \\
\text { Products }\end{array}$ \\
\hline $\begin{array}{l}\text { Inactivated } \\
\text { vaccines }\end{array}$ & $\begin{array}{l}\text { Inactivated pathogen, } \\
\text { product development and } \\
\text { manufacturing process } \\
\text { highly established }\end{array}$ & $\begin{array}{l}\text { Less reactogenicity, } \\
\text { weaker immune } \\
\text { response }\end{array}$ & $\begin{array}{l}\text { Requires multiple dosages and } \\
\text { adjuvants, slow process of } \\
\text { manufacturing, stringent } \\
\text { quality control }\end{array}$ & $\begin{array}{l}\text { Bharat Biotech } \\
\text { International Ltd. }\end{array}$ \\
\hline $\begin{array}{l}\text { Viral vector- } \\
\text { based vaccines }\end{array}$ & $\begin{array}{l}\text { A virus such as measles or } \\
\text { adenovirus is genetically } \\
\text { engineered to produce } \\
\text { coronavirus proteins in } \\
\text { host cell with vigorous } \\
\text { immune response. }\end{array}$ & $\begin{array}{l}\text { Potent, no need for an } \\
\text { adjuvant, antigens are } \\
\text { expressed natively. }\end{array}$ & $\begin{array}{l}\text { No licensed vaccines use this } \\
\text { method, recombination of } \\
\text { virus during production, } \\
\text { contaminants from human- or } \\
\text { animal-derived material, prior } \\
\text { immunity to vector }\end{array}$ & $\begin{array}{l}\text { - ChAdOx1-S } \\
\text { AZD1222 } \\
\text { (Covishield) by } \\
\text { AstraZeneca/ } \\
\text { University of Oxford } \\
\text { - CanSino Biological } \\
\text { Inc/ Beijing Institute } \\
\text { of Biotechnology } \\
\text { - Sputnik V by } \\
\text { Gamaleya Research } \\
\text { Institute, Russia }\end{array}$ \\
\hline $\begin{array}{l}\text { Viral vector- } \\
\text { based, replicating }\end{array}$ & $\begin{array}{l}\text { May boost the innate } \\
\text { immunity against a wide } \\
\text { range of infectious agent, } \\
\text { the efficacy, and mecha- } \\
\text { nisms are still under study }\end{array}$ & $\begin{array}{l}\text { Potent, no need for an } \\
\text { adjuvant, antigens are } \\
\text { expressed natively }\end{array}$ & $\begin{array}{l}\text { Recombination of virus during } \\
\text { production, contaminants from } \\
\text { human- or animal-derived } \\
\text { material, pre-existing immu- } \\
\text { nity against the vector. }\end{array}$ & $\begin{array}{l}\text { - Merck \& Co/ Themis/ } \\
\text { Sharp \& Dohme/ } \\
\text { Institute Pasteur/ } \\
\text { University of } \\
\text { Pittsburgh }\end{array}$ \\
\hline DNA vaccines & $\begin{array}{l}\text { The nucleic acid is } \\
\text { inserted into human cells, } \\
\text { which then churn out } \\
\text { copies of the virus protein }\end{array}$ & $\begin{array}{l}\text { Room temperature } \\
\text { storage, rapid large- } \\
\text { scale production, } \\
\text { options for multi- } \\
\text { valency, cell-free, no } \\
\text { contaminants, non- } \\
\text { infectious }\end{array}$ & $\begin{array}{l}\text { No licensed vaccines use this } \\
\text { method, weak immuno- } \\
\text { genicity in humans, risk of } \\
\text { carcinogenesis, purity, high } \\
\text { concentration }\end{array}$ & $\begin{array}{l}\text { - Inovio } \\
\text { Pharmaceuticals/ } \\
\text { International Vaccine } \\
\text { Institute } \\
\text { - Cadila Healthcare Ltd. }\end{array}$ \\
\hline RNA vaccines & $\begin{array}{l}\text { The nucleic acid is } \\
\text { inserted into human cells, } \\
\text { which then churn out } \\
\text { copies of the virus protein }\end{array}$ & $\begin{array}{l}\text { Storage, ease of large- } \\
\text { scale production, } \\
\text { options for multi- } \\
\text { valency, cell free, no } \\
\text { contaminants, non- } \\
\text { infectious, no genome } \\
\text { integration risk, no } \\
\text { anti-vector immunity }\end{array}$ & $\begin{array}{l}\text { Scale up of mRNA synthesis, } \\
\text { stability, stringent RNase-free } \\
\text { environment, relatively higher } \\
\text { cost, risk of adverse reaction, } \\
\text { inflammation, }\end{array}$ & $\begin{array}{l}\text { - Moderna/ National } \\
\text { Institute of Allergy } \\
\text { and Infectious } \\
\text { Diseases (NIAID) } \\
\text { - } \\
\text { Pfizer/ BioNTech }\end{array}$ \\
\hline $\begin{array}{l}\text { Virus like } \\
\text { particle }\end{array}$ & $\begin{array}{l}\text { Empty virus shells mimic } \\
\text { the coronavirus structure, } \\
\text { but aren't infectious } \\
\text { because they lack genetic } \\
\text { material. }\end{array}$ & $\begin{array}{l}\text { Non-infectious } \\
\text { Potent }\end{array}$ & $\begin{array}{l}\text { Stability Quality control } \\
\text { Potential contaminants } \\
\text { Assembly into stable particles } \\
\text { Heterogeneity Cold chain } \\
\text { transfer and storage }\end{array}$ & $\begin{array}{l}\text { - Serum Institute of } \\
\text { India/ Accelagen Pty }\end{array}$ \\
\hline $\begin{array}{l}\text { Subunit/ } \\
\text { recombinant } \\
\text { Protein }\end{array}$ & $\begin{array}{l}\text { Injecting coronavirus } \\
\text { proteins directly into the } \\
\text { body. }\end{array}$ & $\begin{array}{l}\text { Non-infectious, less } \\
\text { side effects }\end{array}$ & $\begin{array}{l}\text { Labor-intensive, new produc- } \\
\text { tion process and stability, } \\
\text { assays for each new antigen, } \\
\text { quality control, cold chain } \\
\text { transfer and storage, need for } \\
\text { adjuvants }\end{array}$ & - Novavax \\
\hline
\end{tabular}


Table 2: Key features of vaccines in advanced phase-3 trials

\begin{tabular}{|c|c|c|c|}
\hline Feature & Pfizer & Moderna & Astra Zeneca/Oxford \\
\hline Vaccine type/components & mRNA with lipid nanoparticles & mRNA with lipid nanoparticles & $\begin{array}{l}\text { Chimpanzee adenovirus 5- } \\
\text { vectored (as Covishield) }\end{array}$ \\
\hline Dose & 1, purposeful & 1, purposeful & 2, accidental \\
\hline Control & Placebo & Placebo & $\begin{array}{l}\text { Meningococcal group } \\
\text { conjugate or saline }\end{array}$ \\
\hline $\begin{array}{l}\text { Number of Phase } 3 \\
\text { trials }\end{array}$ & $1(43,548$ participants $)$ & $1(30,000$ participants $)$ & 3 \\
\hline Status of trials & Complete & $\begin{array}{l}\text { Incomplete. Interim non peer } \\
\text { reviewed data }\end{array}$ & Interim \\
\hline Efficacy & $95 \%$ & $94.5 \%$ & $\begin{array}{l}90 \% \text { (1st low dose, } 2 \text { nd full } \\
\text { dose, } n=2741 ; 70 \% \text { for } 2 \text {-full } \\
\text { dose vaccine, } n=8895\end{array}$ \\
\hline 2nd dose & 21 days & 28 days & 28 days \\
\hline Efficacy by subgroup & $\begin{array}{l}\text { High for age, sex, race, } \\
\text { pre-existing conditions }\end{array}$ & High for older people & Unknown for age $>55 y$ \\
\hline Major safety concerns & Nil & Nil & Transverse myelitis $(n=1)$ \\
\hline Approval status & $\begin{array}{l}\text { Emergency use approval in UK, } \\
\text { Mexico, USA, Singapore, } \\
\text { Jordan, and Kuwait. Full approval } \\
\text { in Bahrain, Canada and Saudi } \\
\text { Arabia }\end{array}$ & $\begin{array}{l}\text { Emergency use approval in } \\
\text { USA }\end{array}$ & $\begin{array}{l}\text { Under consideration by } \\
\text { various authorities }\end{array}$ \\
\hline
\end{tabular}

vaccine for its most vulnerable $20 \%$ of its population by the end of 2021. US government announced federal funding by Operation Warp Speed and is supporting 7 different vaccine candidates who are in phase $3{ }^{6}$

\section{VACCINES INADVANCED DEVELOPMENT}

Three vaccines are in advanced development and have progressed to phase 3 trials ( 2 have since been approved, table 2). These vaccines include the Pfizer-BioNTec mRNA based vaccine, Moderna mRNA based vaccine and Oxford Alliance-Astra Zeneca adenovirus vector based vaccine. $^{7,8}$ The salient characteristics of the study conducted on these three vaccines have been summerized in table 2 .

\section{VACCINE CHALLENGES}

Compressed Timelines: A vaccine usually takes 10 to 15 years to develop and approve by the authorities, but with SARS CoV-2, this is being accelerated to 12 to 18 months by combined phases, pre-approval, and rapid large-scale manufacturing before approval. This leaves us with several unanswered questions like ability of vaccines to prevent transmission of $S A R S \mathrm{CoV}-2$, duration of the immunity, requirement of repeated vaccinations, efficacy and safety in older people, ability of vaccine for different mutations, and long term safety concerns. ${ }^{9}$

Technologies: New technologies are being used like RNA and DNA, which have never been used before for mass vaccination. There is some hesitancy in taking vaccines by certain group of people. No prior safety trial of these new techniques will further lead to refusal for vaccination.

Access: High-income countries like Canada, USA, UK, Australia, and the European Union have been able to negotiate with companies of different vaccine candidates for use in their whole populations. India, by virtue of being largest producer of vaccine, has been able to secure more than 2 billion doses by leveraging access to its facility. This has left many low- and lower-middle income countries scrambling for short term supplies. COVAX has been launched to fund these countries and provide access to atleast $20 \%$ of their population.

Manufacturing and Logistics: Since more 16 billion doses ( 2 dose per person) would be required to vaccinate the whole world, it will require huge effort to manufacture them by the industry. Glass vials and injections will be manufactured at unprecedented scale in a short time. Post 
usage disposal will also be a challenge. Transportation of vaccine across the world maintaining the cold chain or ultra-cold chain throughout the supply chain is a major concern. The BioNTech-Pfizer RNA candidate requires storage at $-70^{\circ} \mathrm{C}\left(-94^{\circ} \mathrm{F}\right)$ or colder throughout deployment until vaccination whereas Covishield from AstrazenecaOxford can be stored in a normal refrigerator, which makes rapid distribution more feasible. The whole chain right from the factory to air transport, land transport and right down to the individual will require huge planning, communication and training. Any break in the whole chain can lead to failed efficacy.

\section{CHALLENGES IN LOGISTICS AND DEPLOY- MENT IN INDIA}

Vaccinating over 1.3 billion people against COVID-19 is a mammoth task. Although WHO experts have pointed to a $65-70 \%$ vaccine coverage rate as sufficient to reach population immunity, for a successful vaccination drive choices of vaccines, distribution, identifying groups for early vaccination, storage and more importantly, trained personnel, all play a role. Affordability and ease of administration may outweigh superior quality in driving choices by the countries. A home grown vaccine will be a key. Government of India aims to inoculate 300 million most vulnerable people by August 2021. It has made a committee to finalize on prioritizing the vaccine distribution in the country. It has launched an application CoWIN for registration by common people for the vaccination. It has also released FAQ's on vaccine for making common man aware. ${ }^{10}$

India has around 27,000 "cold chain" stores for stocking vaccines. The cold chain for current vaccines does not require super-freezing sub-zero temperatures but functions well at +2 to +8 degrees Celsius. So, upgrading of cold chain stores and adding more will be needed. As the vaccine is injectable, it can be delivered by trained healthcare personnel only and not by allied workers, which can become a bottleneck. Delivering to rural and remote populations will be challenging globally, also in India. ${ }^{11}$ Mercifully the COVID-19 epidemic in India is largely confined to urban areas. ${ }^{12}$ Government is planning to implement innovative Electronic Vaccine Intelligence Network for enhancing efficiency and diligence. This application helps to monitor vaccine stocks and cold chain efficiency. Documentation of vaccination and the tracking and investigation of vaccine safety events are essential components of monitoring which have traditionally not been done well. So, thinking through the external monitoring or support mechanisms would be helpful. Lastly, preventing fraud in vaccination and fake vaccines being sold in remote markets will be important.

COVID 19 pandemic has exerted tremendous pressure on the scientific community to deliver a safe and effective vaccine at the earliest. Newer technologies have been applied and accelerated time frame has been used for approval of vaccine. Though safety and ethical question remain, emergency use of vaccine has started. Aspects of mass production and public distribution are equally big challenges. Doing it in a fair and equitable manner is essential, ${ }^{13}$ and shall go a long way in success of the vaccine today and in the future.

\section{REFERENCES}

1. Johns Hopkins University Coronavirus Resource Center. COVID-19 dashboard by the Center for Systems Science and Engineering (CSSE) at Johns Hopkins University. Available at: https://coronavirus.jhu.edu/map.html. Accessed 8 Dec 2020.

2. Wang J, Peng Y, Xu H, Cui Z, Williams RO. The COVID-19 vaccine race: Challenges and opportunities in vaccine formulation. AAPS PharmSciTech. 2020;21(6):225.

3. World Health Organization. Draft landscape of COVID-19 vaccine candidates. Available at: https://www.who.int/publications $/ \mathrm{m} /$ item/draft-landscape-of-COVID-19-candidatevaccines. Accessed 8 Dec 2020.

4. Kaur SP, Gupta V. COVID-19 Vaccine: A comprehensive status report. Virus Res. 2020; 288:198114.

5. Frederiksen LSF, Zhang Y, Foged C, Thakur A. The long road toward COVID-19 herd immunity: Vaccine platform technologies and mass immunization strategies. Front Immunol.2020;11:1817

6. https://www.raps.org/news-and-articles/news-articles/ 2020/3/COVID-19-vaccine-tracker. Accessed Dec 18, 2020.

7. Polack FP, Thomas SJ, Kitchin N, Absalon J, Gurtman A, Lockhart S et al. Safety and Efficacy of the BNT162b2 mRNA COVID-19 Vaccine. $N$ Engl J Med. 2020 Dec 10. doi: 10.1056/NEJMoa2034577.

8. Ramasamy MN, Minassian AM, Ewer KJ, Flaxman $A L$, Folegatti PM, Owens DR et al. Safety and immunogenicity of ChAdOx1 $\mathrm{nCoV}-19$ vaccine administered in a prime- 
boost regimen in young and old adults (COV002): A singleblind, randomised, controlled, phase $2 / 3$ trial. Lancet. 2020 ; 396:1979-93.doi:10.1016/S0140-6736(20) 32466-1.

9. Ledford H, Cyranoski D, Van Noorden R. The UK has approved a COVID vaccine - here's what scientists now want to know. Nature. 2020; 588:205-206.

10. https://www.mohfw.gov.in/pdf/FAQsonCOVID19 VaccineDecember2020.pdf. Accessed Dec 18, 2020

11. Bangalee V, Suleman F. Access considerations for a COVID-19 vaccine for South Africa. S Afr Fam Pract. 2020; 62(1):e1-e4.

12. Gupta R, Dhamija RK, Gaur K, Khedar RS. Urban sprawl of COVID-19 epidemic in India: lessons from the first semester. medRxiv preprints. 2020; https://doi.org/10.1101/ 2020.08.17.20176537.

13. Volpp KG, Loewenstein G, Buttenheim AM. Behaviorally informed strategies for a national COVID-19 vaccine promotion program. JAMA. 2020; EPub. DOI: 10.1001/jama.2020.24036.

\section{Corresponding Author}

Dr Rajeev Gupta, Department of Medicine, Eternal Heart Care Centre and Research Institute, Jagatpura Road, Jawahar Circle, Jaipur 301017 India.

Phone:+91-141-5147000;

email: rajeevgg@gmail.com; drrajeev.gupta@eternal heart.org 